依 頼 論 文 •シリーズ : 補綴装置および歯の延命のために Part 5 -ロ腔内環境の劣化一

\title{
口腔内環境の劣化に伴う歯列崩壊，補綴装置生存短縮の病態とその対応
}

\author{
佐藤裕二，北川 昇
}

\section{Problems and Solutions for Dentures in Elderly}

Yuji Sato, DDS, PhD and Noboru Kitagawa, DDS, PhD

抄 録

日本の高龄化率は $25 \%$ を超え, 超高齢社会となっている，要介護高齢者も増え，患者の健康状態や，置 かれている環境も大きく変わってきた。そこで, 本稿では最初に, 補綴装置と歯の延命に関する因子を概 説した。 そのなかで, 口腔環境関連因子の相互関係を整理し, 特に, プラーク, 歯石 (義歯石含む), 義歯 床下粘膜の障害，義歯維持力低下，それぞれに関して，その病態と対応策を述べた，最後に，口腔内環境 の劣化を押さえるだけではなく, 高い質の義歯を作り上げ，患者の環境を最大限に保ち，制限された患者 の機能や環境にあわせた工夫をおこなうことで, さらに義歯の機能を高めることができることを提言した。

和文キーワード

老化, 維持力, 歯石, プラーク, 床下粘膜

\section{はじめに：超高齢社会の現状}

日本の高齢化率は 25\%を超え，超高齢社会となって いる，要介護高齢者も増え，患者の健康状態や，置か れている環境も大きく変わってきた。

残存歯の増加により, 平成 17 年から 23 年にかけて 義歯装着者の「割合」は減少してきているが，高齢者 の増加により, 部分床義歯患者数はほとんど変化せず, 高年齢化している ${ }^{1)}$. 一方, 総義歯は $18 \%$ 減ったが, 85 歳以上は増えている。このことから, 義歯症例の難 易度は上がっていると考えられ, 後期高齢者（75 歳以 上）に対する適切な義歯治療はまだまだ必要であると 思われる。

さらに，年齢の増加は，全身疾患の増加につながる. 当講座の調査 ${ }^{2)}$ では, 糖尿病, 心疾患, 肝炎, 認知症, 通院などに問題がある高齢者は多く, これらが, 診療 を困難にしていることが示されている．また，高齢者 の残存歯は増えたものの, 歯冠修復が多く行われてお

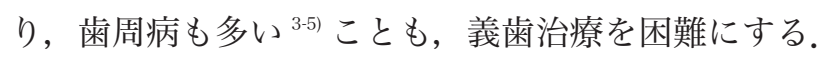
また，両側臼歯部に咬合支持が無い義歯患者の治療は 一般に困難と言われている。摂食嚥下機能も, 各種疾患,
口腔乾燥, 中枢神経・末梢神経の老化, 筋や顎関節の 老化などにより低下 ${ }^{6)}$ する。 また, 要介護高齢者も増 加 $^{7)}$ し, 義歯のケアやメインテナンスが難しくなるこ とも多くなる.

以上のことから, 歯科補綴治療の難易度は上がって いると考えられ, 後期高齢者 (75 歳以上) に対する適 切な歯科補綴治療はまだまだ必要であると思われる。

本稿では, 口腔環境の劣化について整理し, それが どのように歯列崩壊や補綴装置の寿命の短縮につなが るかを概説し，その対応策についてまとめる。

\section{1. 補緅装置と歯の延命に関する因子}

表 1 に補綴装置と歯の延命に関する因子を整理し た. 本誌第 6 巻 1 号から始まったシリーズで既に述べ られた因子は主に「歯」の病的老化（疾患）に関する 物が網羅されている。 今回の Part 5 で扱うのは，「口 腔環境の劣化」であり，これは主に唾液に関する因子 で，網掛けで示すように非常に多くの因子間で関連が ある。これについて概説する。

その他，多くの因子があるが，まだ述べられていな い因子として,「力」があげられる。これは, 食いしばり, $\mathrm{TCH}$ などである。 
表 1 補綴装置と歯の延命に関する因子

\begin{tabular}{|c|c|c|}
\hline 大分類 & 中分類 & 因子 \\
\hline 補綴的要因 & & $\begin{array}{l}\text { 装置の質：診察検査, 診断, 治療 } \\
\text { メインテナンス : 救急対応 }\end{array}$ \\
\hline \multirow[t]{7}{*}{ 局所的要因 } & 歯 & $\begin{array}{ll}\text { 生理的老化: } & \text { 咬耗・摩耗, 着色・変色 } \\
& \text { 歯髄・歯肉・歯根膜の変化 } \\
& \text { 歯列の変化 }\end{array}$ \\
\hline & & $\begin{array}{ll}\text { 病的老化： } & \text { 㛵蝕（歯冠部, 根面） } \\
& \text { 酸蝕症 } \\
& \text { 根尖性歯周炎【Part 3】 } \\
& \text { 外傷（破折【Part 1】, 脱臼【Part 2】） } \\
& \text { 歯周病（歯肉炎, 歯周炎, 咬合性外傷）【Part 4】 }\end{array}$ \\
\hline & 口腔組織 & 粘膜, 舌, 唾液腺, 顎関節, 顎骨, 咀嚼笳, 口唇 \\
\hline & 口腔機能 & 咀嚼・咬合 \\
\hline & & 嚥下 \\
\hline & & 発音 \\
\hline & & 審美 \\
\hline \multirow[t]{2}{*}{ 全身的要因 } & & 生理的老化 \\
\hline & & 病的老化（全身疾患など） \\
\hline 社会心理的要因 & & 食事, 口腔清掃, 通院, コミュニケーション, ストレス \\
\hline
\end{tabular}

※【Part 1】〜【Part 4】は本シリーズで既出

※網掛けは本稿【Part 5】で扱う項目

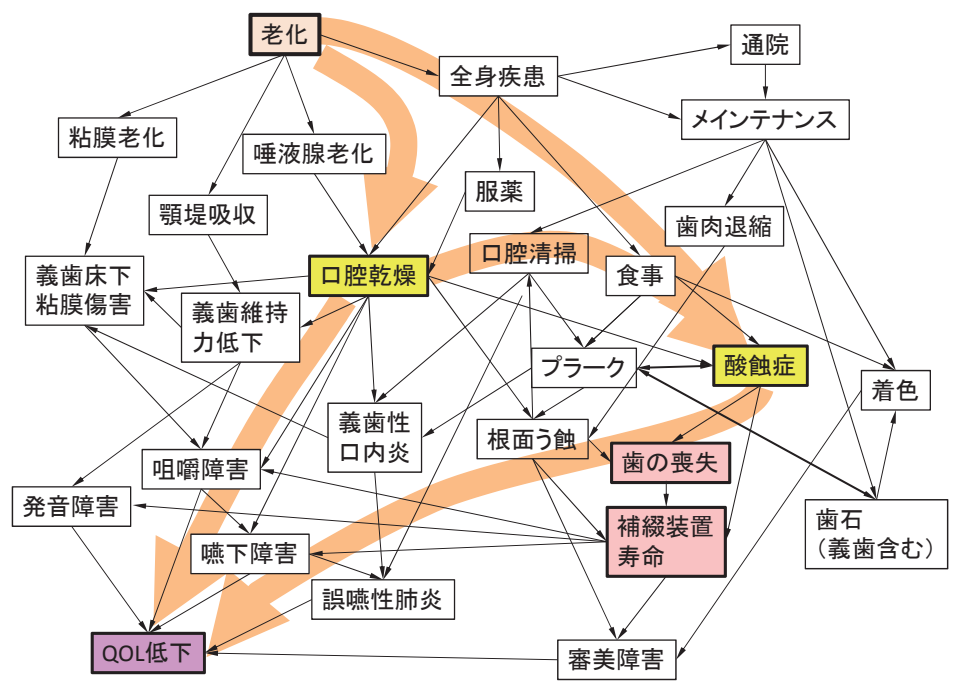

図 1 口腔環境関連因子とその結果の相互関係

\section{2. 口腔環境関連因子の相互関係（図 1 ）}

図 1 に表 1 で示した因子とその結果の相互関係を示 す。う蝕・歯根破折・歯周病は除外してある。老化は 口腔乾燥を引き起こし，咀嚼・䜩下・発音障害を生じ る。一方，口腔乾燥は酸蝕症につながり，歯の喪失・
補綴装置の寿命短縮をもたらし, 各種障害を引き起こ す。これらは最終的には QOL の低下を招く。

口腔乾燥と酸蝕症に関しては前稿で詳細に述べられ ているので，本稿では，周辺の因子に関して述べるこ ととする. 
表 2 根面う蝕への治療・対応（文献 8 を改変）

\begin{tabular}{ll}
\hline 予防 & フッ化物塗布・洗口 \\
& フッ化物徐放性レジン系コート刻塗布 \\
& $3 \mathrm{DS}$ (Dental Drug Delivery System) による除菌 \\
& 定期的な P(M)TC と指導 \\
& 口腔乾燥への対応 \\
\hline 管理 & 活動性う蝕の観察と予防・治療 \\
& 非活動性う蝕の観察と予防 \\
\hline 治療 & 従来型グラスアイイノマーセメント修復 \\
& フッ素徐放性コンポジットレジン充填 \\
\hline
\end{tabular}

※未承認・研究中のものは除外

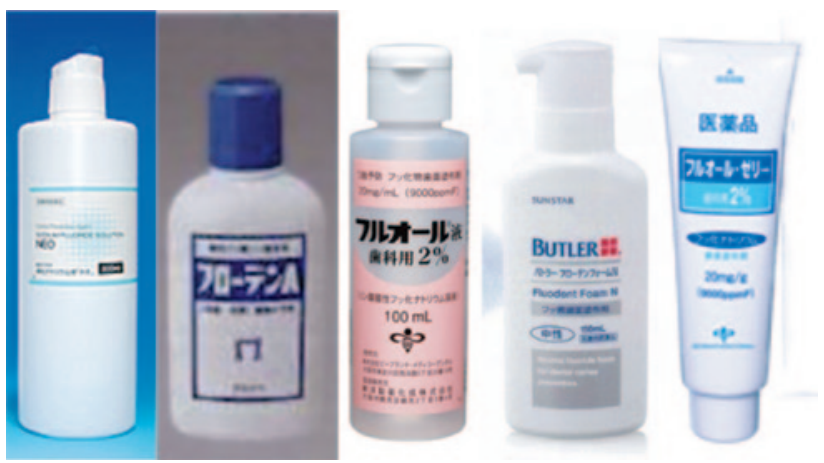

図 2 フッ化物歯面塗布剤

表 3 フッ化物歯面塗布剤

\begin{tabular}{lllc}
\hline 販売名 & 一般名 & 薬事法上の使用目的 & フッ素イオン濃度 \\
\hline 弗化ナトリウム液「ネオ」 & フッ化ナトリウム溶液 & う蝕予防 & $9,000 \mathrm{ppmF}$ \\
フローデンA & 酸性フッ素リン酸溶液 & う蝕予防 & $9,000 \mathrm{ppmF}$ \\
フルオール液歯科用 2\% & リン酸酸性フッ化ナトリウム溶液 & う蝕予防 & $9,000 \mathrm{ppmF}$ \\
フルオール・ゼリー歯科用 2\% & リン酸酸性フッ化ナトリウムゼリー & う蝕予防 & $9,000 \mathrm{ppmF}$ \\
バトラーフローデンフォーム N & フッ化ナトリウム製剤 & う蝕予防 & $9,000 \mathrm{ppmF}$ \\
ダイアデント歯科用ゲル 5\% & フッ化ナトリウム製剤 & 知覚過敏抑制 & $22,600 \mathrm{ppmF}$ \\
Fバニッシュ歯科用 5\% & フッ化ナトリウム製剤 & 知覚過敏抑制 & $22,600 \mathrm{ppmF}$ \\
\hline
\end{tabular}

\section{3. プラークの病態と対応}

口腔乾燥はプラーク（デンチャープラーク含む）の 増加を引き起こす。

1）根面䠘蝕

プラークに唾液の緩衝能の低下と歯肉退縮があい まって，根面う蝕を増加させる。根面う蝕への治療・ 対応 ${ }^{8)}$ について表 2 に示す。このなかで。フッ化物歯 面塗布は 2014 年 4 月に健康保険に導入された。保険 収載のための医療技術提案書 ${ }^{9)}$ に提示されている口腔 衛生学会の書籍 ${ }^{10)}$ によると，使用できるフッ化物歯 面塗布剂 (5 種類) とフッ化物バーニッシュ (2 種類) は図 2 , 表 3 に示す通りである。なお, フッ化物配合 歯磨剤や洗口剂との併用も有効とされている ${ }^{8)}$.

2 ）義歯性口内炎

デンチャープラークは，義歯性口内炎の主因である. しかし，適切な義歯清掃・管理を行えば，大きな問題 になりにくい。ただし，義歯の夜間装着や免疫機能の 低下は義歯性口内炎を引き起こしやすい，義歯性口内 炎は，義歯床下粘膜の傷害や䛊嶼性肺炎の誘因となる。 これらに関しては多くの文献があるので，参照された い.

\section{4. 歯石（義歯石含む）の病態と対応}

プラークが長期間存在すると，唾液中の Ca などが 沈着し，歯石となる。歯に付く歯石に関しては別書に 譲る。義歯に付着する石灰化物（歯石様沈着物）は単 に歯石（dental calculus）とも呼ばれるが，混乱を避 けるためにここでは義歯石 (denture calculus) と呼 ぶ（図 3)。唾液腺開口部のある上顎臼歯部煩側や下顎 前歯部舌側に付着しやすいとされている。また，凹凹 があったり, 粘膜部では適合不良の部位にできやすい.

この除去には，器具で擦ったり，超音波スケーラー を用いられることもあるが，義歯床表面を傷つける恐 れがある，簡易的には，酸性溶液（エッチング剤，食 酢など）を塗布し，しばらく待つと，軟化するので, 手用器具 (できれば木製) で軽く擦ると容易に除去で きる（図 4)。ただし，凹んだ部位の義歯石はなかなか 除去できない，義歯作製時に，不要な凹部を作らない ことも考慮すべきであろう（図 5).

歯科医院専用の洗浄剂もあるが，着色除去用と義歯 石除去用が別々な物もあるので，適切に使用すること が肝要である。 小さなチャック付きポリエチレン袋に 入れて使うと (図 6), 1 回約 $60 \mathrm{cc}$ になるので, 20 30 円の費用である. 


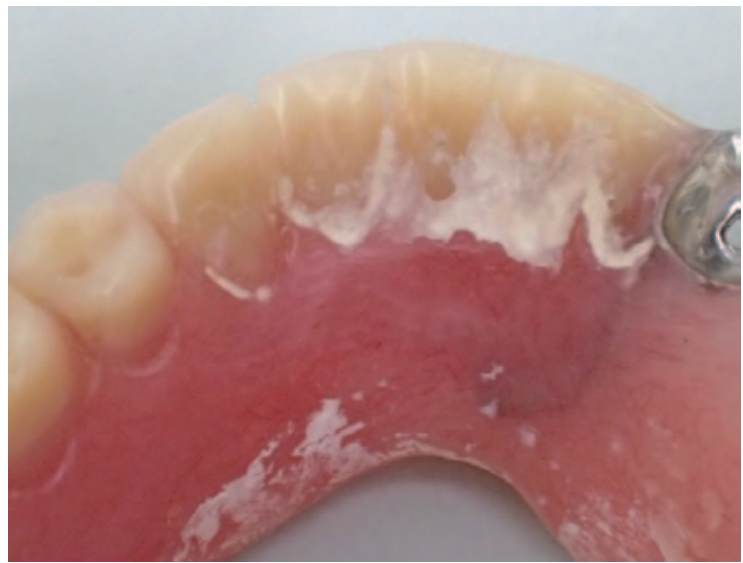

図 3 下顎義歯前歯部舌側に付着した石灰化物（義歯石）

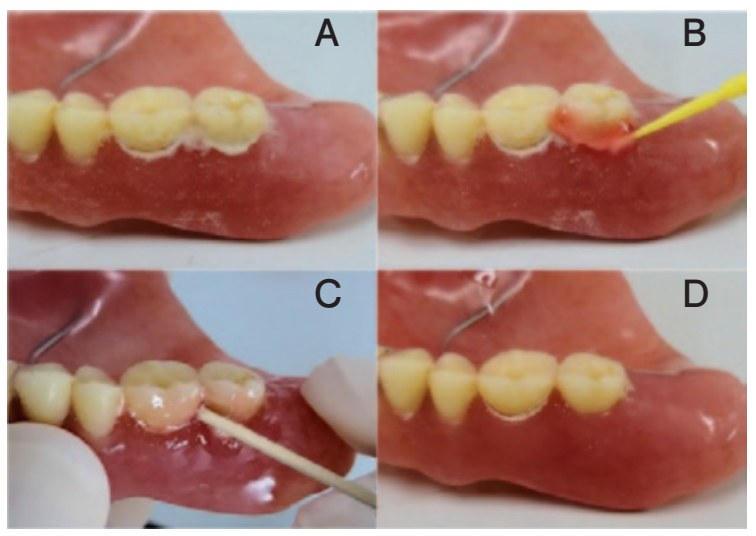

図 4 義歯石の除去手順
A. 上顎義歯臼歯部煩側歯頝部に付着した義歯石
B.コンポジットレジン修復用エッチング液を塗布
C. 手用器具による除去
D．深い歯頭部の義歯石は容易には除去できない

また，診療室における義歯洗浄と歯科衛生士による 義歯管理指導の指針 (案) ${ }^{11}$ が日本老年歯科医学会か ら出されているので，以下の手順を参考にすると良い.

(1)患者の義歯管理状況を十分に聞き取る.

(2)義歯を口腔内より撤去し，十分な照明下で表面を 観察する.

(3)水洗下で, 義歯用ブラシを用いて, 食椬やデン チャープラークを除去する。

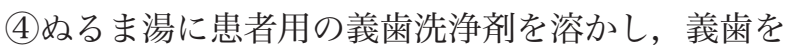
浸漬し，10 分程度，超音波洗浄にかける。

(5)義歯を乾燥させ，十分な照明下で着色や歯石を確 認する。

(6)歯科医院専用義歯洗浄剂を使用する（着色用また は義歯石用).

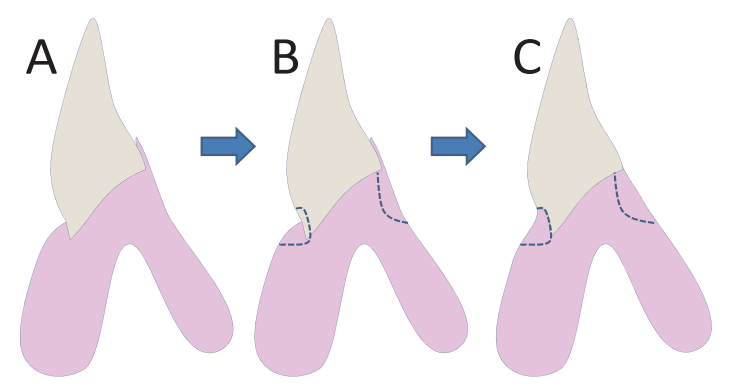

図 5 義歯形態の修正
A. 深い歯肉形成や薄いレジンのバリには義歯石が 付着しやすい
B．修正すべき部分を点線のように削除する
C.レジンを添加し，深い歯肉形成や薄いレジンの バリを無くす

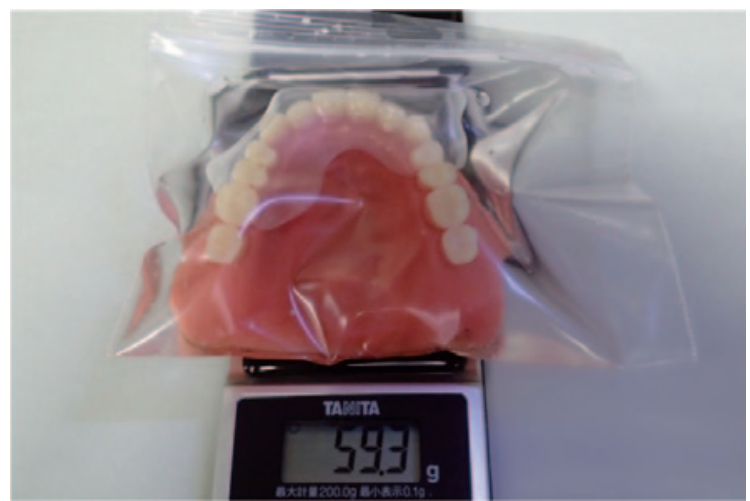

図 6 義歯石除去用洗浄剂に使用（約 $60 \mathrm{cc）}$

(7)メーカーの指示に従つて, 洗浄を行う.

(8)よく水洗し, 乾燥させて, 照明を当てて沈着物の 残存や亀裂の有無などをチェックする.

(9)義歯床表面が粗糙であると再付着しやすいので,

付着しやすい部位は仕上げ研磨をする。

(10義歯の適合，咬合，維持などを診察する.

\section{5. 義歯床下粘膜の障害の病態と対応}

高齢者の口腔粘膜の加齢変化は十分に解明されてい ないため，一致した見解が得られるに至っていない. これは，加齢が様々な因子により修飾されているから であろう。

一般に，高齢者の口腔粘膜は，菲薄平滑で，伸縮性 が低下している ${ }^{12)}$. 組織学的には，角化の減少，弾性 
線維の崩壊・コラーゲン線維の増加による弾力性の低 下, 毛細血管の減少による代謝能の低下や組織の萎縮 が認められる ${ }^{12)}$ 。 われわれの研究 ${ }^{13)}$ では, 高齢無歯顎 者の粘膜は厚く，軟らかいため，小さな圧力で若年有 歯顎者と同程度の沈下量を示した時に疼痛を生じた。 したがって, 義歯による咬合荷重負担能力は小さい. さらに, 口腔乾燥や各種疾患がこれを助長していると 考えられる。つまり，高齢義歯患者に対しては，より 慎重で適正な治療が必要と考えられる.

具体的には，医療面接，診察，検査，診断，前処置， 印象採得，咬合採得，設計，試適，装着，修理，メイ ンテナンスのそれぞれが適切でなくてはならない ${ }^{14)}$.

\section{6. 義歯維持力低下の病態と対応}

高齢者においては, 顎堤の吸収や口腔乾燥により, 義歯の維持力が低下しがちと考えられる. たとえ乾燥 していなくとも，唾液が漿液性であると，維持力が小 さくなる ${ }^{15,16)}$.

口腔乾燥症への対応も重要であるが, 患者は義歯安 定剂を使用することもある。日本補綴歯科学会の「歯 の欠損の補綴歯科診療ガイドライン 2008」によると， 「義歯安定剤を使用することは絶対悪いというエビデ ンスは認められない. 不良な顎堤形態や口腔乾燥など の義歯使用に不利な口腔内状態の高齢者では，有効で あると推奨される。とされている。しかしな゙ら,「ホー ムリライナーは流れが悪く, 短期間のうちに顎堤に大 きなダメージを与えることが懸念されている.」うえに， 「微生物の成長促進，エナメル質脱灰，細胞毒性などに より口腔粘膜に炎症を起こさせる危険性」が指摘され ている，特に口腔乾燥があり, 口腔清掃が不十分な場 合には，問題になろう。

一方，口腔乾燥の患者は口腔保湿剂を使用すること もある．義歯安定剤よりは清掃しやすい利点があり, ジェルタイプの保湿剤は短期的には義歯安定剂と同等 の義歯維持力を発揮させるという報告もある ${ }^{15,16)}$. 我々 は, 現在, 保湿剂の義歯維持力増強効果について, 研 究を進めており，近いうちにその結果を公表できる見 込みである。

\section{おわりに}

高齢化が進む中で，患者の環境は劣化してくる，そ のため, 歯列崩壊や補綴装置生存短縮を生じる。ただ, 義歯の質が悪いことを無視して，「患者の環境の劣化」 のせいにしてはならない。 また，「良い義歯を入れれば おわり」でも困る，高い質の義歯を作り上げ，患者の
環境を最大限に保ち, 制限された患者の機能や環境に あわせた工夫をおこなうことで，さらに義歯の機能を 高めることができ，ひいては，歯列崩壊や補綴装置生 存短縮を防止できるであろう ${ }^{17)}$.

\section{文献}

1）佐藤裕二, 一色ゆかり。歯科疾患実態調査と人口動態調 查を用いた高齢義歯患者絶対数の推定. 日歯医療管理 誌 $2014 ； 49 ： 162-167$.

2）山口麻子, 北川 昇, 佐藤裕二, 桑澤実希, 今井智子. 病院歯科における高齢者歯科医療の難易度評価関連因 子の検討. Dental Med Res 2011 ; 31 : 151-160.

3) 厚生労働省. 平成 11 年歯科疾患実態調查の概要. http:// www.mhlw.go.jp/topics/0105/tp0524-1.html\#kekka [Accessd 15. 10. 2014]

4) 厚生労働省. 平成 17 年歯科疾患実態調查結果について. http://www.mhlw.go.jp/topics/2007/01/tp0129-1. html [Accessd 15. 10. 2014]

5）厚生労働省. 平成 23 年歯科疾患実態調査. http://www. mhlw.go.jp/toukei/list/62-23.html [Accessd 15. 10. 2014]

6）菊谷 武. 高齢者における摂食燕下障害. 植松 宏, 稲葉 繁，渡邊 誠編。高齢者歯科ガイドブック，第 1 版, 東京 : 医歯薬出版 ; 2003, 241-247.

7) 内閣府, 平成 24 年版 高齢社会白書(全.体版). http:// www8.cao.go.jp/kourei/whitepaper/w-2012/zenbun/ index.html [Accessd 15. 10.2014]

8）千田 彰. 超高齢社会における根面う蝕の予防と治療. ザ・クインテッセンス 2014 ；33(6) : 1290-1296.

9）厚生労働省。医療技術評価提案書（保険未収載技術 用 ）【概要版】. http://www.mhlw.go.jp/stf/shingi/ r985200000 lva4h-att/2r985200000 lvadj.pdf [Accessd 15. 10. 2014]

10）一般社団法人日本口腔衛生学会. フッ化物応用の科学, 東京：口腔保健協会；2010，111-120.

11）日本老年歯科医学会，診療室における義歯洗浄と歯科 衛生士による義歯管理指導の指針 (案), 2013, http:// www.gerodontology.jp/file/info/130626/guideline. pdf

12）植松 宏，稲葉 繁，渡邊 誠編. 高齢者歯科ガイド ブック，東京：医歯薬出版；2003，126.

13）小谷祐子, 佐藤裕二, 北川 昇, 下平 修, 竹内沙和子, 磯部明夫ほか. 高齢無歯顎者の義歯床下粘膜の性状と 疼痛閾值の関係. 日補綴会誌 $2014 ; 6 \cdot 123$ 回特別号： 184 (抄録)。

14）佐藤裕二，教科書にのせたい義歯診療のコッ，京都： 永末書店 ; 2012 .

15) Yamagaki K, Kitagawa N, Sato Y, Okane M and Mashimo J. The relationship between the physical properties of oral moisturizers and denture retention, J J Gerodont 2012; 26: 402-411. 
16) Aoyagi K, Sato Y, Kitagawa N, Okane M, Kakuda T, Takayama M. Development of a simple chair-side evaluation method for complete denture retention forces and its reproducibility. J J Gerodont 2014; 29: 21-28.

17）佐藤裕二，義歯の違和感・不具合 患者さんの機能低 下を忘机ていない？。QDT 2014；39，58-75.
著者連絡先: 佐藤裕二

干 145-8515 東京都大田区北千束 2-1-1 昭和大学歯学部高齢者歯科学講座

Tel: 03-3787-1151

Fax: 03-3787-3971

E-mail: sato-@dent.showa-u.ac.jp 